\title{
LIABILITY FOR INNOCENT BUT NEGLIGENT MISREPRESENTATIONS
}

\section{ARTHUR L. GOODHART $\dagger$}

Actrougr I was never a member of the Yale Law School, I did have the great privilege of attending Professor Arthur Corbin's class on the law of contracts when I was in my senior year in Yale College in 1911-12. It was the clarity of the thoughts which he expressed in these lectures, and the force of the arguments with which he, in the kindest possible manner, demolished some of the views expressed by his students, including myself, that convinced me that the law was a subject of the most profound interest. I have therefore accepted with pleasure the invitation to contribute to the essays that have been written as a tribute to him. I cannot say anything that would be original concerning the branch of American law of which he is the greatest living master, so it has occurred to me that it might be of interest to him if I were to deal briefly with the recent English case of Hedley Byrne \& Co. v. Heller \& Partners, $L t d .,^{1}$ which has given rise to much discussion. The problems in that case are of the kind that he has dealt with so successfully during his whole career, for they demand the accurate analysis which has made his books and articles of such great value.

The facts of the case can be stated briefly. The appellants (the plaintiffs) are a firm of advertising agents who in 1957 placed orders for advertising with certain newspapers and television programs for one of their customers, the Easipower Company. They themselves became personally liable for the pay. ment, as is the trade practice. When they became concerned about the financial position of their customer, they instructed their bank to make inquiries. The bank thereupon telephoned to the respondents (defendants), who were merchant bankers, for a statement concerning the Easipower's credit-worthiness, as they were the company's bankers and had taken part in financing it. The respondents had stipulated that the information would be regarded as confidential and without responsibility on their part. The respondents knew that their statement to the appellants' bank would be forwarded to a customer, but they had no specific knowledge of his identity. Thereafter the company was forced into liquidation, and, as a result, the appellants incurred heavy liability for the advertisements that they had placed. They brought the present action against the respondents to recover this loss on the ground that their replies had been given negligently, in breach of the duty to exercise reasonable care.

The trial judge, McNair, J., held that the respondents had been negligent in giving the references, but that they owed no duty of care to the appellants as there was no contractual or fiduciary relationship between them. The Court of Appeal ${ }^{2}$ affirmed his judgment on the authority of Candler v. Crane,

†Emeritus Professor of Law, Oxford University. Editor, the Law Quarterly Review.

1. [1964] A.C. 465.

2. [1962] 1 Q.B. 396. 
Christmas \& $\mathrm{Co}^{3}$ The House of Lords unanimously affirmed the judgment of the Court of Appeal, but it did so on a ground which the courts below had not emphasized. Their Lordships first held that the respondents could not be held liable for the financial injury caused by the negligent reference because there had been a disclaimer by the bank which prevented the creation of any duty of care. ${ }^{4}$

Yet the real significance of the Hedley Byme case lies not in this holding, but rather in their Lordships' apparent reversal of the established rule of the Court of Appeal that no duty of care is owed in the absence of a fiduciary relationship. In holding that this rule rested on unsound precedent, the House of Lords may well have worked a significant change in the law of contracts.

Before dealing with the important questions of substantive law to which this case has given rise, some reference must be made to the question whether or not the conclusions reached by the House of Lords in regard to this substantive law were obiter. This question has been the subject of lengthy discussions in Great Britain, because of the great practical importance of the answer under the English system of absolutely binding precedents. As the American courts are not strictly bound by precedent cases this problem of authority is of less importance to them. The courts, therefore, do not have to spend a considerable part of their time in an attempt to solve the problem whether a particular point in a previous decision was or was not technically a part of the ratio decidendi. They are, therefore, not concerned with the order followed in stating the various reasons for reaching a particular conclusion. Nor do they have to weigh the particular words used in the opinions to see whether they were intended to state a definite or only tentative answer. The courts are, therefore, free to give more weight to the persuasiveness of the arguments than to their binding authority.

Since only those conclusions which are a necessary part of the decision are regarded as authoritative and so followed without hesitation in subsequent cases all other statements concerning possible rules of law are considered merely persuasive. Generally it is not overly difficult to distinguish between the two, but the problem may become an almost insoluble one when a court in arriving at a decision discusses two possible grounds on which it can be based. If the court states clearly that in reaching its decision it has considered both grounds, then both are authoritative, but if it bases its decision on only one of the two grounds, leaving the other unanswered, then anything that has been said in regard to the latter is obiter dictum. Thus if, in the present case, their Lordships had suggested that they were basing their 'decision solely on the ground that the respondents had disclaimed all responsibility for the reference

3. [1951] 2 K.B. 164. In that case the Court of Appeal, by a majority (Lord Denning dissenting), had held that a negligent misrepresentation by an accountant did not give rise to a cause of action as there had been no fiduciary or contractual relationship between the representor and the representee.

4. [1964] A.C. at $489-93$.

5. Id. at $482-89$. 
they had given, then any further views that their Lordships might have expressed regarding the duty of care would have been obiter. Rather than take such a direct course, however, they considered and answered both grounds. The fact that the narrower ground is stated first does not mean that the wider second holding is less a part of the ratio decidendi. It is true that British courts are inclined to limit their judgments to a narrow ground, finding it more prudent to leave the courts free to answer the wider question in future cases. In the present case, however, there were two clear reasons why the more courageous course was adopted. First, the courts below clearly had based their decisions on the ground that no duty of care was owed by the respondents to the appellants, and this was the question which had been argued at great length by counsel on appeal. It would, therefore, have seemed almost discourteons to disregard the question, or having discussed it, to leave it unanswered. The second reason for following the course that was taken in the present case is that the question of duty of care which it involved was of great immediate importance. It is almost certain that some facets of negligent misrepresentation will be dealt with by legislation in the near future, so that it was highly desirable that the courts should express a view on the existing law. ${ }^{6}$

There is no more striking illustration of the difficulties to which the strict doctrine of precedent may, on some occasions, give rise than the history of the law regarding liability for negligent misrepresentation. ${ }^{7}$ Twice the House of Lords attempted to state the law in clear and precise terms, but each time, after a period in which the announced rule was applied by the lower courts, it became necessary to re-interpret the terms because, as originally understood and applied, the rules led to unsatisfactory results. ${ }^{8}$ Neither in these two cases nor in most of the other misrepresentation cases have the judges considered at any length the reasons on which the rules which they are entunciating are or ought to be based; they have concentrated on the conclusions reached in the precedent cases without paying regard to the fact that these conclusions may have been based on circumstances that have altered radically in recent years. Nor have they ever considered whether or not these precedents have worked well in practice or whether they are suited to an unforeseen situation that has now arisen. ${ }^{9}$ While such law is eventually corrected, it often takes an unconscionable time to do so. If the precedent decision has been one by the

6. See Law Reform Committee, Tenth Report (Imnocent Misrepresentation), Cmd, No. 1782 (1962).

7. Professor Warren A. Seavey has described in a most interesting manner the effect of precedents in the American and in the English law of torts. Seavey, Candler v. Crant, Christmas \& Co.: Negligent Misrepresentation by Accountant, 67 L.Q. Rev. 466 (1951).

8. Derry v. Peek, 14 App. Cas. 337 (1889); Noctor v. Lord Ashburton, [1914] A.C. 932.

9. In Scruttons, Ltd. v. Midland Silicones, Ltd., [1962] A.C. 446, Viscount Simonds said: "The law is developed by the application of old principles to new circumstances. Therein lies its genius." Id. at 468. The diffectlty is that in some cases new circumstances may require the application of new principles because it may not be possible to say conclusively that the new circumstances ought to fall within the ambit of old principles. 
House of Lords, it may take forty years before some litigant is prepared to embark on the dangerous and expensive adventure of seeking to persuade the House that its judgments did not mean what everyone hitherto thought that they did.

The story of the law of misrepresentation may conveniently begin with Mr. Justice Stirling's opinion in Peek v. Derry, ${ }^{10}$ better known under its title in the House of Lords - Derry v. Peek. ${ }^{11}$ In this leading case a tramway company had, under a private Act of Parliament, the right to run either horsedrawn trams or, if the Board of Trade consented, trams driven by steam or mechanical power. The directors issued a prospectus which stated that "the Company has the right to use steam or mechanical motive power instead of horses ...."12 On the strength of this statement, the plaintiff took shares in the company, but thereafter the Board of Trade refused its consent, and the company had to be wound up. When Sir Henry Peek sued the directors in an action for deceit the jury found that they had failed to exercise reasonable care when making the false statement, but that they had not done so knowingly or recklessly. Mr. Justice Stirling gave judgment for the defendants on the ground that an innocent but negligent statement, however unreasonable it might be, was not sufficient to support an action for deceit. The Court of Appeal reversed the judgment, holding that the directors had negligently made a false statement of fact for which they were liable, although they had not done so with any fraudulent intent. Sir James Hannen said: "It appears to me that nothing can morally justify a man in stating a thing as a fact, as existing at present, because he expects that it will exist in the future."13 In a note on this case in the Law Quarterly Review, ${ }^{14}$ Sir Frederick Pollock said that there was good sense in the phrase "legal fraud" on which the Court had acted, because "legal or constructive fraud means and ought to mean something which is not fraud but to which the policy of the law has attached the same consequences; just as in constructive delivery there is a change of possession without actual delivery." 15 The next year Pollock published another note in which he said: "[T] he law is rapidly tending towards the enforcement (contrary, no doubt, to old authorities and to some recent ones) of a general duty to be careful, as well as to abstain from wilful harm, in statements as well as in acts."10 In his view negligent statements would, like negligent acts, give rise to liability.

Pollock was unduly optimistic in making this prophecy, for it has in fact taken the law exactly seventy-five years to reach the conclusion that he supported in 1889. He did not realize that in the following year the House of Lords would, in Derry v. Peek, ${ }^{17}$ unanimously reverse the judgment that the
10. 37 Ch. D. 541 (1888).
11. 14 App. Cas. 337 (1889).
12. $37 \mathrm{Ch}$. D. at 552 .
13. Id. at 584 .
14. 4 L.Q. REv. 369 (1888).
15. Ibid.
16. 5 L.Q. REv. 103 (1889).
17. 14 App. Cas. 337 (1889). 
Court of Appeal had delivered. Their Lordships held that however negligent the directors might have been in misstating the facts in the prospectus, they could not be held liable for the tort of deceit if they had not known that their statement was untrue, or concerning the truth of which they were indifferent.

In an article entitled Derry v. Peek in the House of Lords ${ }^{18}$ Pollock criticized this decision in unusually strong terms : he recognized that it was binding on the English Courts, but he urged "many courts administering the Common Law, but not bound by the decisions of English courts,"19 not to follow it. This comment was undoubtedly directed in part to the courts of the United States. In discussing the earlier authorities, he cited Chief Justice Best's statement in Adamson v. Jarvis ${ }^{20}$ that: "He who affirms either what he does not know to be true ... or knows to be false, to another's prejudice and his own gain, is both in morality and law guilty of falsehood and must answer in damages." 21 In plain words, a man may be held to lie even though he thinks that he may be telling the truth. Pollock concluded, "[i]t seems to me that the decision of the House of Lords has dangerously relaxed the legal conception of honesty in the statement of facts, and will do no good, to say the least, to commercial morality."22 $\mathrm{He}$ expressed the hope that a different conclusion would be reached "in other English-speaking countries if not here. It remains to be seen whether the decision in Derry v. Peek will do more, even here, than retard and complicate the process."23

A reply to Pollock's article by Sir William Anson was published in the next number. ${ }^{24} \mathrm{He}$ stated that the Court of Appeal had mistakenly "extended the liability from the dishonest representation of a non-existent belief, to the honest representation of a belief not based on reasonable grounds."20 Under the law as stated by the House of Lords the plaintiff must show that the statement was not innocent, in other words that it was not only false but fraudulent. He concluded with a reference to "those who believe the Common Law, as it stands, to be a monument of practical common sense."20 It is of interest to note that within a year Parliament took a contrary view concerning the practical common sense of the law laid down in Derry v. Peek in regard to a prospectus, when it enacted the Directors Liability Act of 1890, which provided that a director is liable for untrue statements in a prospectus unless he proves that he had reasonable grounds to believe and did believe that they were true. The fact that Parliament did not proceed at this time to alter the law as a whole may be explained on the ground that it wished to deal as soon

18. 5 L.Q. REv. 410 (1889).

19. Id. at 410 .

20. 4 Bing. 66 (1827).

21. Pollock, supra note 18, at 412 (1889) (emphasis omitted).

22. Id. at 422 .

23. Id. at 423 .

24. 6 L.Q. Rev. 72 (1890).

25. Id. at 73.

26. Id. at 74 . 
as possible with the particular problem of a company prospectus and that a more general act would have caused delay because of the difficulty of drafting it in precise terms.

Three years later, in Le Lievre v. Gould, ${ }^{27}$ the Court of Appeal purported to follow Derry v. Peek. The defendant, an architect and surveyor, gave inaccurate certificates to his employer, a builder, concerning the work that had been done on a building under construction. The builder, without the defendant's knowledge, showed them to the plaintiffs, who relied on them in making a loan to the builder. When the loan was not repaid, the plaintiffs brought an action against the defendant for deceit. The case could have been decided in favor of the defendant on two grounds: (a) that he had no reason to foresee that the plaintiffs might be shown the certificates, and (b) that the plaintiffs ought to have relied on their own surveyor. The Court of Appeal, however, chose to base its decision on a wider ground. Thus, Lord Esher said that "in the absence of contract, an action for negligence cannot be maintained when there is no fraud."28 Lord Justice Bowen said that the law of England "does not consider that what a man writes on paper is like a gun or other dangerous instrument, and, unless he intended to deceive, the law does not, in the absence of contract, hold him responsible for drawing his certificate carelessly." comparison of a piece of paper, on which something is written, with a gun is not a particularly happy one; a writing may be just as dangerous as any weapon, as many persons have discovered at their cost..$^{30}$

Thus the general effect of the judgments in Derry v. Peek was to give an impression to the courts, and to the legal profession as a whole, that only when actual fraud had been proved could misrepresentors be held liable for damages; it was fraud, properly so-called, or nothing.

In 1914, however, in the case of Nocton v. Lord Ashburton, 31 the House of Lords held that the judgments in Derry v. Pcek had been misunderstood. Lord Haldane said: "I think that the authorities subsequent to the decision of the House of Lords show a tendency to assume that it was intended to mean more than it did. In reality the judgment covered only a part of the field in which liabilities may arise." 32 According to this view, if anyone had been astute enough when the action of Peek $v$. Derry was commenced to frame it in regligence, a different conclusion might have been reached. It is incredible that no one thought of this. In the Nocton case the appellant, a solicitor, advised the respondent to release part of a mortgage, so that the security became insufficient, and he suffered loss. The court held that there had been no fraud

27. [1893] 1 Q.B. 491.

28. Id. at 498 .

29. Id. at 502 .

30. On this point Professor Seavey said: "Words may be as dangerous as guns. Arsenic labelled salt is more dangerous than dynamite labelled dynamite." Seavey, supra note 7 , at $472 \mathrm{n} .21$.

31. [1914] A.C. 932.

32. Id. at 947 . 
sufficient to found an action for deceit, but that the client might claim relief in equity for constructive fraud. Lord Haldane said that "although liability for negligence in word has in material respects been developed in our law differently from liability for negligence in act, it is nonetheless true that a man may come under a special duty to exercise care in giving information or ad. vice." 33

In the various judgments in the Nocton case emphasis was laid on the fiduciary relationship between the representor and the representee. Thus Lord Haldane said: "Such a special duty may arise from the circumstances and relations of the parties. These may give rise to an implied contract at law or to a fiduciary obligation in equity."34 Illustrations of a fiduciary relationship are those of solicitor and client, father and child, guardian and ward, and trustee and beneficiary. The emphasis placed on the word "fiduciary" suggested that this exception to the general rule of non-liability for a negligent misrepresentation was strictly limited.

For the next fifty years this interpretation of the law as stated in the Nocton case was the governing one, and it was on this interpretation that Candlor 7 . Crane, Christmas \& $\mathrm{Co}^{35}$ was founded.

But before discussing the Candler case reference must be made to the famous case of Donoghue $v$. Stevenson, ${ }^{36}$ which the House of Lords decided in 1932. The majority of the House held that a manufacturer of ginger beer could be held liable to a woman who became ill after finding a decomposed snail in one of the defendant's bottles, given to her by a friend. The importance of the case lies in the principle it established that liability is not limited to those who are in direct relationship with a manufacturer, but extends to the ultimate user of the article. Lord Atkin stated that the basic principle was "you must not injurc your neighbour" and that in the eyes of the law, neighbour ment "persons who are so closely and directly affected by my act that I ought reasonably to have them in contemplation as being so affected when I am directing ny mind to the acts or omissions which are called in question." 37 This principle was stated with even greater precision in Grant $v$. Australian Kritting Mills, ${ }^{\text {, }}$ in which the field of tort liability was extended beyond that in the Donogluic case. Lord Wright said: "No distinction, however, can be logically drawn for this purpose between a noxious thing taken internally and a noxious thing applied externally . . .."39 In neither of these cases was there any stuggestion that there was a special relationship between the plaintiff and the defendant;

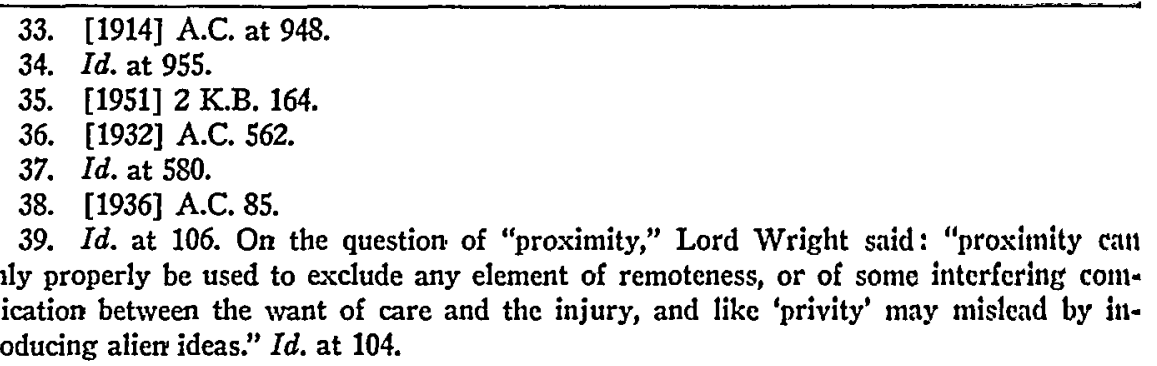


for that matter, the crux of these cases was that there was no such relationship. Liability was based on the fact that the defendant ought reasonably to have anticipated that someone in the position of the plaintiff would be affected by his act. These cases, however, were concerned with a defect in a material thing giving rise to a physical injury, so it could be argued that they were not direct precedents for a case of defective representation giving rise to nonphysical injury, such as financial loss.

We can now return to the Candler case in which the relevance of Donoghue v. Stevenson to negligent misrepresentations was a major point in issue. The majority of the Court of Appeal (Asquith and Cohen, LL.J.) held that no duty of care to third persons lay on the defendant, an accountant, who had negligently, though in good faith, prepared a company's grossly misleading balance sheet, fully aware that the balance sheet would be shown to the plaintiff who was preparing to advance money to the company. There was no contract or fiduciary relationship in these circumstances, and, therefore, they said, no liability. They held that Donoghue v. Stezenson had not introduced any change in the law relating to misrepresentation, because had Lord Atkin intended to do so, he would not have referred to the Gould case with implicit approval.40 Lord Justice Asquith pointed out that it might not be logical to draw a distinction between negligent acts and negligent words, but that the distinction could be explained by the different histories of the two forms of liability.11

Lord Justice Denning dissented. Recognizing that the Donoghue case could be distinguished on the facts, he nevertheless thought that the general principle of liability ought to be similar both for acts and for words. It had been argued that the distinction ought to be based on the nature of the injury that followed from the negligent act or words ; $;^{42}$ thus if they gave rise to a non-physical "injury, such as financial loss, there would be no liability for a negligent misrepresentation. Lord Justice Denning, however, was not convinced by this argument. He argued that the court was not bound by the prior decision in Le Lievre v. Gould..$^{43}$ That decision had been based on the idea that liability depends on a close and direct relationship. It reflected the then current legal notion which was infected by two cardinal errors. The first was that no one who is not a party to a contract can sue on it or on anything arising out of it; the second, based on a misunderstanding of Derry $\%$. Peek, was that no action ever lies for a negligent statement, even though it is intended to be acted on by the plaintiff, and is in fact acted on by him to his loss. He argued that there was a duty of care in regard to the representations made by persons "such as accountants, surveyors, valuers, and analysts, whose profession and occupation it is to examine books, accounts and other things, and to make reports on which other people - other than their clients - rely in the ordinary course
40. [1951] 2 K.B. at $189-90$.
41. Id. at 195.
42. Id. at 179.
43. [1893] 1 Q.B. 491. 
of business." 44 Whether such a list was intended to be exclusive must be considered as we return to the Hedley Byrne case. ${ }^{45}$

As has been pointed out above, both Mr. Justice McNair and the majority of the Court of Appeal held in Hedley Byrne that they were bound by the decision in the Candler ${ }^{40}$ case as the facts could not be distinguished. It was not necessary, therefore, for them to discuss the law at any length.

When the Hedley Byrne case reached the House of Lords their Lordships overruled the Candler case. They did this by holding that the Court of Appeal in Candler had misinterpreted Nocton $v$. Lord Ashburton. ${ }^{47}$ The wheel had thus come full circle, for in Derry v. Peek the House of Lords had apparently denied that there was any liability for a negligent but innocent misrepresentation, although there was considerable authority against such a strict view. In the Nocton case the House of Lords held that this was a misinterpretation of Derry v. Peek because liability existed whenever there was a fiduciary relationship between the parties. Now in Hedley Byrne their Lordships have held this to be too narrow an interpretation, as there is such liability whenever a special relationship between the parties gives rise to a duty of care.

Therefore this special relationship is all-important; but it is not always easy to determine what facts are necessary to create such a relationship. Their Lordships do not seem to have been in agreement on this point. To add to the uncertainty, we are faced with two types of misrepresentation: (a) the misu representation that leads to a physical injury; and, (b) the misrepresenta. tion that leads to a direct financial injury.

Although the judgments in Hedley Byrne are silent concerning the first type of misrepresentation, it can be assumed with confidence that in these circumstances the special relationship is the "neighbour" relationship of Donoghue v. Stevenson, i.e., a duty of care to any one who could reasonably be foreseen to be endangered. ${ }^{48}$ If a bottle of poison is mislabeled "non-poisonous" there is a duty of care to anyone anywhere who may foreseeably drink the contents. Thus it might be said that in Donoghue $v$. Stevenson there was a misrepresentation that the bottle of ginger beer did not contain a decomposed snail.

When we turn to the second type of misrepresentation, that leading to a financial injury, the judgments in Hedley Byrne suggest that the "neighbour" principle would be too wide in these circumstances. Lord Devlin said:

44. [1951] 2 K.B. at 179.

45. [1964] A.C. 465.

46. Candler v. Crane, Christmas \& Co., [1951] 2 K.B. 164.

47. Nocton v. Lord Ashburton; [1914] A.C. 932.

48. See the comments on this point in Hedley Byrne, [1964] A.C. at 496 (Lord Morris of Borth-y-Gest), 506 (Lord Hodson), 515 (Lord Devlin). Lord Pearce said:

The House in Donoghue v. Stevenson was, in fact, dealing with negligent acts causing physical damage, and the opinions cannot be read as if they were dealing with negligence in word causing economic damage. Had it been otherwise soma consideration would have been given to problems peculiar to negligence in words. Id. at 536 . 
It is a responsibility that is voluntarily accepted or undertaken, either generally where a general relationship, such as that of solicitor and client or banker and customer, is created, or specifically in relation to a particular transaction .... I do not think it possible to formulate with exactitude all the conditions under which the law will in a specific case imply a voluntary undertaking any more than it is possible to formulate those in which the law will imply a contract. ${ }^{40}$

This may give rise to some uncertainty, for in many misrepresentation cases the last thing that the representor intended to do was to accept voluntarily any responsibility: when the law, therefore, is said to "imply a voluntary undertaking," this means that the law will hold the representor liable "as if" he had undertaken the responsibility. This does not, however, furnish us with a satisfactory answer, because it does not tell us why the law has made the implication. Thus it will be useful to consider with some care the various judgments delivered in the present case so as to ascertain what facts are essential to the creation of the relationship.

Lord Reid said:

There must be something more than the mere misstatement . ... The most natural requirement would be that expressly or by implication from the circumstances the speaker or writer has undertaken some responsibility ....50

In regard to the possible distinction between fiduciary and special relationships he said:

I can see no logical stopping place short of all those relationships where it is plain that the party seeking information or advice was trusting the other to exercise such a degree of care as the circumstances required, where it was reasonable for him to do that, and where the other gave the information or advice when he knew or ought to have known that the inquirer was relying on him. I say "ought to have known" because in questions of negligence we now apply the objective standard of what the reasonable man would have done. ${ }^{: 1}$

He pointed out that a reasonable man, knowing that his skill and judgment were being relied on, would have three courses open to him: (a) he could decline to give the information or advice sought; (b) he could give an answer with a clear qualification that he accepted no responsibility for it; or (c) he could simply answer without any such qualification. ${ }^{62}$ Lord Reid concluded that if a person chooses to adopt the last course, he must be held to have accepted some responsibility for giving his answer carefully. With great respect, it may be suggested that this third course is not as simple as it seems to be. If a headmaster is asked to give a reference for a former pupil, he will hesitate to state that he accepts no responsibility in giving it; on the other hand, it may be an undue burden to require him to make prolonged researches in the files
49. Id. at $529-30$.
50. Id. at 483 .
51. Id. at 486 .
52. Ibid. 
or consult his colleagues. Ought not the degree of care that he must show depend on the circumstances of each case? Thus the reference for a man who is being recommended for a position of high responsibility would be of a different character from that given for a man seeking an ordinary job. If the various courses open to a person asked for advice are divided into definite categories, then there is certain to be a large number of border-line or hybrid cases. Would it not be more convenient, and probably more just, to leave it to the judge or the jury in each case to determine whether the representor has used the care that a reasonable man, placed in his position, would have used?

Lord Reid doubted whether Donoghue v. Stevenson had any direct bearing on the present case because he thought that the law "must treat negligent words differently from negligent acts." ${ }^{33}$ There were two major differences between them: (a) persons often express casual words, but "it is at least unusual casually to put into circulation negligently made articles which are dangerous;" 54 and (b) a negligently made article will cause only one accident, but in regard to negligent words "it would be going very far to say that he owes a duty to every ultimate 'consumer' who acts on those words to his detriment." 55 In regard to (a) it may be suggested, with respect, that it is less unusual than Lord Reid implies to put into circulation articles that may be dangerous if negligently made because it is the possibility of being dangerous that is relevant. Thus the millions of motor vehicles that are manufactured or repaired each year all fall within the Donoghue v. Stevenson principle. It is doubtful whether the number of statements that could cause a direct financial loss if they contained a negligent misrepresentation greatly exceed this figure. If they do, there must be something wrong in our economy. Where they do most frequently cause a loss, as in the case of certain hire-purchase sales, the law would benefit if it were made more responsive.

In regard to (b), the problem is a more difficult one because the claim might be made, for example, by an ultimate "consumer" who had purchased shares many years after a prospectus containing a misrepresentation had been issued. The answer to this is that in practice such claims would not be brought owing to the difficulty of proving causation. The Directors Liability Act of 1890, as re-enacted in subsequent company law legislation has not given rise to the flood of litigation that was predicted at that time.

Lord Morris also placed emphasis on the assumption of responsibility. He said :

[I] $A$ assumes a responsibility to $B$ to tender him deliberate advice, there could be a liability if the advice is negligently given. I say "could be" because the ordinary courtesies and exchanges of life would become impossible if it were sought to attach legal obligation to every kindly and friendly act. 50

53. Id. at 482 .

54. Id. at 483 .

55. Ibid.

56. Id. at 494 . 
He suggested that it is sufficient to create liability if $A$ gives $B$ reasonable grounds for believing that he has assumed responsibility. Later in his judgment ${ }^{57}$ he quoted Lord Moulton's statement in Heilbut, Symonds \& Co. $v$. Buckleton that it was of the greatest importance to "maintain in its full integrity the principle that a person is not liable in damages for an innocent misrepresentation, no matter in what way or under what form the attack is made." $"$ It is not clear why it is important to maintain in its full integrity a principle that seems to lead to injustice in those cases in which the representor has been negligent in making the representation that has misled the representee.

Lord Hodson pointed out that Lord Haldane's reference in the Nocton case to a special duty based on "an implied contract at law or to a fiduciary obligation in equity" 59 had been construed in too limited a sense by the Court of Appeal in Candler's case. This illustrates the confusion to which the strict doctrine of precedent may give rise; if the courts in those cases had been less concerned with the precise words of precedent judgments and had placed more weight on the reasoning of the cases, such misunderstandings could have been avoided. Now the idea of a fiduciary relationship has been replaced by that of a special relationship, but as Lord Hodson pointed out, that does not get us very far. He therefore concluded that, "I do not think it is possible to catalogue the special features which must be found to exist before the duty of care will arise in a given case. . . " 60 This is of importance because it gives to a court which has to determine liability in a case relating to negligent misrepresentation the same freedom which is given to a court when deciding liability for a defective article. Lord Hodson ended his judgment with these words:

I agree with him [Lord Morris of Borth-y-Gest] that if in a sphere where a person is so placed that others could reasonably rely upon his judgment or his skill or upon his ability to make careful inquiry such person takes it upon himself to give information or advice to, or allows his information or advice to be passed on to, another person who, as he knows or should know, will place reliance upon it, then a duty of care will arise.01

While covering the facts in the Hedley Byrme case, there is a danger that this statement may be construed as exclusive in nature just as the phrase "fiduciary relationship" in the Nocton case was construed too narrowly in the subsequent cases. Thus if $\mathrm{X}$ makes a negligent misrepresentation to $\mathrm{Y}$ knowing that $Y$ will rely on it, can $X$ thereafter raise the defense that $Y$ ought reasonably to have known that he, $X$, had neither judgment, skill nor competence?

Lord Devlin began his judgment with a statement which at first sight seems to be self-evident, but which is, in fact, of the greatest interest. He said that:

\footnotetext{
57. Id. at 502 .

58. [1913] A.C. $30,51$.

59. [1964] A.C. at 508 .

60. Id. at 514 .

61. Ibid.
} 
there is no general duty not to make careless statements. No one challenges that hypothesis .... Nor indeed is there any general duty to be careful in action. The duty is limited to those who can establish some relationship of proximity such as was found to exist in Donoghue v. Stevenson. A plaintiff cannot, therefore, recover for financial loss caused by a careless statement unless he can show that the maker of the statement was under a special duty to him to be careful. ${ }^{62}$

This would suggest that there are different tests for acts and for words, in that liability for negligent acts depends on proximity, while liability for negligent words depends on a special relationship giving rise to a special duty to be careful. This apparent difference disappears, however, when we realize that neither the word "proximity" nor the phrase "special relationship" has any precise meaning. The duty of reasonable care depends on proximity, but on the other hand, as Lord Atkin said in Donoghue v. Stevenson, proximity is a relation. ship which means that "you must take reasonable care to avoid acts or omissions which you can reasonably foresee would be likely to injure your neighbour." 83 It is merely a form of circumlocution to say that reasonable care depends on proximity, and that proximity is a relationship which is based on reasonable care. It disguises the essential point that in every case the question is one of fact: has the defendant shown reasonable care in the circumstances? This cannot be answered by the vague word "proximity." The same circumlocution is found in the phrase "special relationship." The duty to be careful depends on the special relationship, but the relationship is a special one because it is based on the premise that the circumstances demand special care.

Such circumstances, it is suggested, arise whenever one person can foresee that his representation will be relied on by another. Solicitors, surveyors or other professional men are subject to this duty of care, because in their cases it is clear that there will be such reliance; but this does not mean that others will not be subject to the same duty of care if, for other reasons, they can foresee that reliance will be placed on them.

Lord Devlin suggested that the correct test for this liability could be stated in these words: "Is the relationship between the parties in this case such that it can be brought within a category giving rise to a special duty ?"OA He recognized that this will give rise to some difficulty because, "as always in English law, the first step in such an inquiry is to see how far the authorities have gone, for new categories in the law do not spring into existence overnight." In other words, it is apparently necessary to find the relevant category before determining whether the representor can be held to be under a duty of care. These categories can include a relationship which arises from a single act "if the doing of that act implied a voluntary undertaking to assume responsibility. ${ }^{60}$ His Lordship said that "this is a point of great importance because it

62. Id. at 514-15.

63. [1932] A.C. at 580.

64. [1964] A.C. at 525.

65. Ibid.

66. Id. at 529 . 
is, as I understand it, the foundation for the ground on which in the end the House dismisses the appeal."07 He stated his own test as follows:

I shall therefore content myself with the proposition that wherever there is a relationship equivalent to contract, there is a duty of care. Such a relationship may be either general or particular .... Where, as in the present case, what is relied on is a particular relationship created ad hoc, it will be necessary to examine the particular facts to see whether there is an express or implied undertaking of responsibility. ${ }^{\text {cs }}$

The novel phrase "equivalent to contract" means that "there is an assumption of responsibility in which, but for the absence of consideration there would be a contract." ${ }^{\prime 2}$ This, with great respect, is not an easy concept to apply for it requires an interpretation of the rules of contract. Moreover, it suggests that the liability for misrepresentation is essentially contractual in nature, although it gives rise to an action in tort.

On the other hand, Lord Pearce emphasized that the action was essentially tortious. He said:

How wide the sphere of the duty of care in negligence is to be laid depends ultimately upon the courts' assessment of the demands of society for protection from the carelessness of others. Economic protection has lagged behind protection in physical matters where there is injury to person and property. It may be that the size and the width of the range of possible claims has acted as a deterrent to extension of economic protection. ${ }^{70}$

This, if we may say so, raises a most important consideration in regard to misrepresentation. Professor Seavey made a similar point when he suggested that the reason why the Anglo-American courts do not apply the same rules to liability for harm to pecuniary interests not involving physical harm that they do to liability for physical harm is primarily an economic one. ${ }^{71}$ This economic argument is based on the fear that an expansion of the area of liability will subject persons who have made careless statements to great and indefinite liability. It seems that the American courts have been progressively less affected by this fear, but like the English courts, they have not yet been able to agree on a general principle of liability.

Finally Lord Pearce suggested that to import a duty of care, "the representation must normally, I think, concern a business or professional transaction whose nature makes clear the gravity of the inquiry and the importance and influence attached to the answer."72 This limitation will not in practice be an important one, because it is already clear that a misrepresentation which leads to a physical injury gives rise to liability. It is therefore difficult to think of

67. Ibid.

68. Id. at 530.

69. Id. at 529 .

70. Id. at 536.

71. Seavey, supra note 7 , at 474.

72. Id. at 539. 
any misrepresentation which gives rise to financial injury which will not be concerned with a business or professional transaction.

These quotations from the judgments in Hedley Byrne show that their Lordships were unanimous in holding that liability for an innocent but negligent misrepresentation will arise whenever there is a special relationship unless a disclaimer of responsibility for the representation has been made. But these quotations also show that there is some uncertainty concerning what is meant by "special relationship," and how its existence can be ascertained if it does not fall within one of the traditional categories. There is, therefore, a danger that the present case may, like Derry v. Peek and Nocton v. Lord Ashburton, give rise to involved debates concerning its proper interpretation. Such debates, it may be suggested with diffidence, could be avoided if the concept of "special relationship," with all its ambiguities, were deleted from the law and in its place were substituted, as Sir Frederick Pollock stuggested seventy-five years ago, a general duty to exercise reasonable care not to injure others by false statements, just as there is a duty not to injure them by harmful acts. Such a duty of care would depend on the facts of each case; in certain circumstances more care need be exercised than in others. Thus if a man is paid for his advice, it is reasonable that he should exercise greater care than if he is asked to give it gratuitously. Again, if a matter of great importance is involved, greater care will be required than where there is no such importance. Similarly, the relationship of the parties to each other will be a fact to tako into consideration, but these relationships need not be strictly divided into categories of special and non-special relationships, because a relationship which may give rise to liability in circumstances $A$ may not give rise to liability in circumstances $B$.

To base the law concerning misrepresentation on a general principle, would not, I believe, create a revolution in the practical effect of the law. The fenrs that were expressed when Donoghue $v$. Stevenson was decided that there would be a flood of unjustifiable cases have proved to be groundless. Similar $1 y$, the fear that the recognition of general liability for false statements would open the "flood gates of litigation" as counsel for the respondents argued in Hedley Byrne ${ }^{73}$ may prove to be equally exaggerated, for in every case it would be necessary to prove that there had been a failure to take reasonable care in the circumstances. There is no reason to anticipate that the reasonable man of the common law will fail here when he has proved so stuccessful elsewhere.

In conclusion, a reference to the 10th Report of the Lazw Reform Committed on Innocent Misrepresentation, ${ }^{74}$ which was issued in July 1962, may be of interest. The committee was instructed "to consider whether any alterations are necessary or desirable in the law relating to innocent misrepresentation and the remedies available for such misrepresentation." "75 It made eight recom-

73. [1964] A.C. at 474.

74. I was a member of the Law Reform Committee which presented this report so I am prejudiced in its favor.

75. Law Reforar Committee, Tenth Report, Innocent Mifskepresentation 3 (1962). 
mendations which have not yet been implemented, as they are still being considered by the Lord Chancellor.

By far the most important recommendation was recommendation (5) which suggested that:

Where a person has, either by himself or his agent, induced another to enter into a contract with him (including a contract relating to land) by an untrue representation made for the purpose of inducing the contract he should be liable in damages for any loss suffered in consequence of the representation unless he proves that up to the time the contract was made he (or his agent, if the representation was made by him) believed the representation to be true and had reasonable grounds for his belief. ${ }^{70}$

This recommendation strongly supports the conclusion reached by the Housc of Lords in the present case. It is, however, limited to the liability of a party to a contract or his agent.

The committee did not consider the point at issue in the present case, the liability of a third person giving a reference. On this point it is said briefly, "The tort of deceit still will be needed for those cases where a fraudulent statement has induced a person to act to his detriment otherwise than by entering into a contract."77 It must not be assumed that this statement implied that the law ought not to be amended so as to hold a person liable for an innocent but negligent misstatement in these circumstances. The committee felt that this was a separate question of great difficulty: an attempt to deal with it in the report would have meant a long delay. The committee's recommendation goes further than the conclusion reached by the House of Lords in the present case, because it recommends that the burden of proof that the misrepresentation was made without negligence should fall on the person making the representation. Such a shift in the burden of proof is a reasonable one, but it may be open to the objection that English law is in general opposed to making a defendant prove a negative. On the other hand, as the committee pointed out in paragraph 18, there is a precedent for such a provision in section 43 of the Companies Act of 1948.78 That section makes those responsible for the issue of a prospectus inviting persons to subscribe for shares or debentures in a company liable for any untrue statement in the prospectus unless they can show that they had reasonable ground to believe, and did up to the time of the allotment believe, that the statement was true. ${ }^{70}$

\footnotetext{
76. Id. at 14 .

77. Id. at 11 .

78. Companies Act, 1948, 11 \& 12 Geo. 6, c. 38, § 43.

79. Ibid.
} 